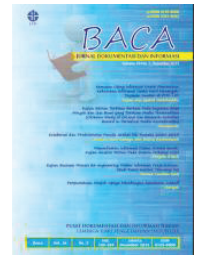

\title{
KARAKTERISTIK KEPENULISAN DAN KARAKTERISTIK ARTIKEL PADA JURNAL PSIKOLOGI UNIVERSITAS GADJAH MADA: KAJIAN BIBLIOMETRI
}

\author{
Pergola Irianti \\ Perpustakaan Universitas Gadjah Mada
}

Korespondensi: pergola_irianti@ugm.ac.id

Diajukan: 4 November 2016; Direview: 15 Februari 2017; Diterima: 24 Maret 2017; Direvisi: 3 April 2017

\begin{abstract}
The purpose of this study is to know how the characteristics of authorship, authors involvement, and characteristics of the articles in the Jurnal Psikologi UGM 1976-2015 period. In this descriptive quantitative study, data were collected by documentation method. Jurnal Psikologi UGM is research subject, and all of article in the journal is unit analysis. Data were collected by documentation method while the data were analyze by the percentage formula and presented by table of frequency. As many as 53 numbers of Journal of Psychology UGM were collected. The results showed percentage of women author are $(60,12 \%)$ higher than men. Most of them are lecturer $(52,95 \%)$ and college students $(35,30 \%)$, from the Faculty of Psychology Universitas Gadjah Mada $(62,30 \%)$ and the other $(37,70 \%)$. Education level of writer, post graduate $(80 \%)$ higher than bachelor $(20 \%)$. Joint authorship $(56,88 \%)$ are higher than single authorship $(43,11 \%)$, with the collaboration level of 0,56 . Highest frequency the involvement of the authors is Faturochman as many as 16 articles. Most articles use Indonesian language (92,96\%), and the rest in English. Long of article between 11-15 pages (41,9\%) highest. Based on subject, Clinical and Counseling Psychology $(25,5 \%)$ highest, and then Social Psychology $(25,1 \%)$, Educational Psychology and Psychometrics (24,5\%). Based on research methods of article, 67,22\% articles using quantitative survey methods.
\end{abstract}

\begin{abstract}
ABSTRAK
Tujuan penelitian ini untuk mengetahui karakteristik kepenulisan, keterlibatan penulis, dan karakteristik artikel dalam Jurnal Psikologi UGM tahun 1976-2015. Dalam penelitian kuantitatif deskriptif ini, data dikumpulkan dengan metode dokumentasi. Subjek kajian adalah Jurnal Psikologi UGM dan semua artikel menjadi unit analisis. Metode analisis data menggunakan rumus persentase dan disajikan dengan tabel frekuensi. Ada 53 nomor publikasi Jurnal Psikologi UGM yang terkumpul. Hasil analisis menunjukkan bahwa persentase penulis perempuan $(60,12 \%)$ lebih tinggi dibandingkan laki-laki. Sebagian besar dari mereka adalah dosen $(52,95 \%)$ dan mahasiswa $(35,30 \%)$. Instansi asal penulis dari Fakultas Psikologi Universitas Gadjah Mada (62,30\%) dan lainnya (37,70\%). Tingkat pendidikan penulis pascasarjana $(80 \%)$ lebih tinggi dari pada sarjana (20\%). Kepenulisan bersama (56,88\%) lebih tinggi dari pada penulis tunggal $(43,11 \%)$, dengan tingkat kolaborasi 0,56 . Keterlibatan penulis tertinggi, yaitu sebanyak 16 artikel dicapai oleh Faturochman. Penggunaan bahasa Indonesia sebagai bahasa pengantar meraih persentase tertinggi $(92,96 \%)$ dan selebihnya dalam bahasa Inggris. Panjang artikel antara 11-15 halaman mencapai persentase tertinggi (41,9\%). Dari segi subjek kajian, Psikologi Klinis dan Konseling (25,5\%) tertinggi, diikuti dengan subjek Psikologi Sosial $(25,1 \%)$, serta Psikologi Pendidikan dan Psikometrik $(24,5 \%)$. Berdasarkan pendekatan metode penelitian, $67,22 \%$ artikel menggunakan metode survei kuantitatif.
\end{abstract}

Keywords: Bibliometric; Writing characteristic; Article; Authorship 


\section{PENDAHULUAN}

Publikasi ilmiah perguruan tinggi berupa jurnal merupakan salah satu bentuk media komunikasi ilmiah antar-ilmuwan dalam bidang ilmu tertentu. Muatan informasi jurnal berupa hasil pemikiran dan penelitian yang telah dilakukan oleh para ahli sesuai bidangnya. Dwiputrianti (2016) mengemukakan bahwa penerbitan jurnal bertujuan untuk menyosialisasikan hasil penelitian berdasarkan data dan fakta di lapangan baik di tingkat lokal, nasional, regional, maupun internasional. Jurnal yang diterbitkan lembaga pendidikan tinggi dan organisasi profesi di Indonesia dapat mencerminkan kuantitas dan kualitas karya yang telah dilakukan oleh para ahli dan peneliti sesuai dengan bidangnya masing-masing. Berdasarkan data di PDII-LIPI, pada tahun 2012 ada sekitar 7.000 majalah ilmiah atau jurnal yang terbit di Indonesia, tetapi hanya sekitar 300 jurnal yang terakreditasi. Menurut Hartinah (2012) kondisi ini dipengaruhi oleh terbatasnya kemampuan akademisi menulis karya ilmiah, terutama mereka yang berdomisili di daerah.

Dalam rangka meningkatkan karya ilmiah di Indonesia, Direktorat Jendral Pendidikan Tinggi telah mengeluarkan surat edaran yang ditujukan kepada pimpinan perguruan tinggi negeri maupun swasta di seluruh Indonesia perihal publikasi karya ilmiah. Surat edaran dengan nomor 152/E/T/2012 tertanggal 27 Januari 2012 menyebutkan adanya prasyarat wajib kelulusan mahasiswa S1, S2, dan S3 untuk menghasilkan makalah yang diterbitkan pada jurnal ilmiah. Makalah program sarjana diterbitkan pada jurnal ilmiah, program magister diterbitkan pada jurnal ilmiah nasional terakreditasi Dikti, dan program doktor diterbitkan pada jurnal internasional. Peraturan yang lainnya, yaitu Peraturan Menteri Pendayagunaan Aparatur Negara dan Reformasi Birokrasi Nomor 17 Tahun 2013 dan Peraturan Menteri Pendidikan dan Kebudayaan Nomor 92 Tahun 2014 tentang kenaikan jenjang jabatan akademik dosen, mewajibkan dosen mempublikasikan karya ilmiahnya pada jurnal nasional terakreditasi dan jurnal internasional bereputasi di bidangnya. Kebijakan tersebut menunjukkan bahwa pemerintah memberikan suatu arah agar kualitas publikasi ilmiah di Indonesia dapat ditingkatkan. Meskipun demikian, dalam rapat kerja LIPI 2 Maret 2016, di Auditorium LIPI, Jakarta, dengan tema "Menuju Etos Kerja Profesional dan Tata Kelola Efektif Untuk Peningkatan Kinerja LIPI" Menristek Mohamad Nasir mengemukakan bahwa karya ilmiah yang berhasil dipublikasikan hanya sekitar 4500-5500 dari target yang ditentukan sebesar 6000-6500 karya. Kondisi tersebut menunjukkan bahwa karya ilmiah di Indonesia secara kuantitas dan kualitas belum sesuai dengan harapan (Nasir, 2016).

Uraian di atas menunjukkan bahwa sasaran utama peningkatan publikasi ilmiah Indonesia adalah perguruan tinggi. Oleh karena itu, sudah selayaknya setiap fakultas yang berada dalam lingkup perguruan tinggi melaksanakan kebijakan tersebut. Fakultas Psikologi Universitas Gadjah Mada (UGM) sebagai bagian dari perguruan tinggi di Indonesia telah menerbitkan publikasi berkalanya yang bernama Jurnal Psikologi UGM dengan bidang keilmuan psikologi. Muatan informasinya berupa hasil-hasil penelitian ilmu psikologi yang telah dilakukan oleh staf pengajar dan mahasiswa program studi sarjana, magister, dan doktor di lingkungan Fakultas Psikologi UGM. Penerbitannya dilakukan sejak tahun 1970-an dan sampai saat ini, Jurnal Psikologi UGM telah menyajikan artikel karya staf pengajar dan mahasiswa dalam lingkup internal maupun eksternal.

Permasalahan kajian ini adalah bagaimana karakteristik kepenulisan dan karakteristik artikel Jurnal Psikologi UGM. Masalah tersebut diuraikan ke dalam beberapa pertanyaan: (1) bagaimana frekuensi kepenulisan ditinjau dari jenis kelamin, instansi asal, jenis pekerjaan, tingkat pendidikan, jumlah penulis, dan tingkat kolaborasi?; (2) siapa penulis yang terlibat dalam 
penulisan artikel jurnal tersebut dan bagaimana frekuensinya?; (3) bagaimana frekuensi artikel ditinjau dari bahasa pengantar, panjang artikel, subjek artikel dan metodologi yang digunakan? Kajian ini bertujuan untuk: (a) mengetahui frekuensi kepenulisan artikel ditinjau dari jenis kelamin, instansi asal, jenis pekerjaan, tingkat pendidikan, jumlah penulis, dan tingkat kolaborasi; (b) mengetahui penulis dan frekuensi keterlibatannya dalam penulisan artikel; dan (c) mengetahui frekuensi artikel ditinjau dari bahasa pengantar, panjang artikel, subjek artikel, dan metodologi yang digunakan. Manfaat yang diharapkan dari kajian ini yaitu: (a) sebagai bahan evaluasi penerbitan jurnal di Fakultas Psikologi UGM; dan (b) menambah khazanah kajian bidang kepustakawanan terkait dengan bibliometri.

\section{TINJAUAN PUSTAKA}

Kajian ini merupakan kajian bibliometri, yaitu kajian yang menggunakan dokumen dan pola publikasi dengan menerapkan metode matematika dan statistika (Pritchard dalam SulistyoBasuki, 2002). Kajian bibliometri telah banyak dilakukan di dalam negeri dan luar negeri. Beberapa kajian di luar negeri antara lain dilakukan oleh Thanuskodi (2011) pada Indian Journal Chemistry tahun 2005-2009. Kajian ini difokuskan pada: (1) persentase jumlah artikel berdasarkan tahun penerbitan; (2) pola kepenulisan yang meliputi instansi asal penulis, daerah asal penulis; dan (3) pola artikel yang meliputi panjang artikel dan jenis literatur yang disitir. Ray dan Basak (2013) melakukan kajian bibliometri pada Journal of Documentation mengenai kolaborasi pengarang, subjek artikel, dan daerah asal kontributor artikel.

Das (2013) juga melakukan kajian bibliometri pada jurnal Library Trends. Kajiannya mencakup pola kepenulisan, analisis sitiran, kontribusi artikel berdasarkan tahun penerbitan, dan panjang artikel. Panda dkk. (2013) melakukan kajian bibliometri pada The Journal of Information Literacy. Kajiannya terfokus pada kolaborasi pengarang, kontribusi artikel berdasarkan tahun penerbitan, dan rerata jumlah sitiran. Mishra, dkk. (2014) melakukan kajian bibliometri pada disertasi di Inggris. Kajian ini fokus pada jumlah disertasi yang dihasilkan pada tahun 1975-2007, frekuensi jumlah disertasi berdasarkan tahun, dan jumlah halaman disertasi.

Kajian bibliometri di dalam negeri antara lain pernah dilakukan oleh Purnomowati dan Yuliastuti (2000) dengan judul "Pola Kepengarangan dalam Majalah BACA Tahun 1974-1999". Pokok kajiannya meliputi: jenis kelamin, jenis pekerjaan, dan instansi asal penulis. Selanjutnya, pada tahun 2004, Purnomowati melakukan kajian berjudul "Ciri-ciri Kepengarangan dan Penggunaan Literatur dalam Majalah Indonesia Bidang Ilmu-ilmu Sosial”. Fokus kajian meliputi: jenis kelamin, jenis pekerjaan, instansi asal, dan negara asal penulis. Irianti (2011) melakukan kajian mengenai pola kepengarangan pada Jurnal Psikologi UGM periode 20012010. Kajian tersebut fokus pada tingkat kolaborasi dan jenis kolaborasi, dengan hasil tingkat kolaborasi sebesar 0,5 dan jenis kolaborasi dosen-mahasiswa (D-M) menduduki peringkat tertinggi. Sutardji dan Maulidyah (2014) melakukan kajian bibliometri pada Buletin Palawija yang difokuskan pada kolaborasi penulis, tingkat kolaborasi, impact factor, paruh hidup literatur, dan jenis literatur yang dirujuk. Himawanto (2015) melakukan kajian bibliometrika riset minyak dan gas bumi nasional tahun 1990-2014, mengenai topik-topik penelitian yang diangkat pada periode tersebut, keterlibatan peneliti berdasarkan geografis, serta kolaborasi peneliti. Berdasarkan uraian di atas dan sepengetahuan penulis, kajian karakteristik kepenulisan Jurnal Psikologi UGM periode 1976-2015 belum pernah dilakukan. Oleh karena itu, pada kesempatan ini, penulis melakukan kajian terkait dengan hal tersebut. 


\subsection{Bibliometrika}

Menurut Diodato (1994), bibliometrika berasal dari kata biblio dan metric. Biblio berarti 'buku' dan metric berarti 'mengukur' atau 'menganalisis'. Jadi, pengertian biliometrika adalah melakukan analisis terhadap buku menggunakan pendekatan matematika dan statistika. The British Standards Institution mendefinisikan bibiliometrika sebagai kajian penggunaan dokumen dalam pola publikasi dengan menerapkan metode matematika dan statistika. Dokumen dalam hal ini dapat berupa media komunikasi yang sudah direkam dalam bentuk grafis (cetak) atau elektronik (Sulistyo-Basuki, 2002). Tujuan umum bibliometrika untuk merancang bangun sistem dan jaringan informasi yang lebih ekonomis, penyempurnaan tingkat efisiensi pengolahan informasi, identifikasi dan pengukuran efisiensi pada jasa bibliografi, meramalkan kecenderungan penerbitan, serta penemuan dan elusidadi hukum empiris yang dapat menyediakan basis bagi pengembangan sebuah teori dalam ilmu informasi (Brookes dalam Sulistyo-Basuki, 2002).

Manfaat penerapan aplikasi bibliometrika, antara lain: (a) identifikasi kecenderungan penelitian bidang ilmu tertentu; dan (b) identifikasi kecenderungan penulis dalam bidang ilmu tertentu (Glanzel, 2003). Hampir sama dengan pendapat tersebut, Sulistyo-Basuki (2002) mengemukakan manfaat penerapan bibliometrika, antara lain: (a) identifikasi arah gejala penelitian dan pertumbuhan pengetahaun pada disiplin ilmu tertentu; (b) mengenali kepenulisan dan arah gejalanya pada dokumen tertentu; (c) meramalkan arah gejala perkembangan masa lalu, sekarang, dan yang akan datang; serta (d) meramalkan produktivitas penerbit, pengarang, organisasi, negara, dan disiplin ilmu tertentu.

\subsection{Karakteristik Kepenulisan Artikel IImiah}

Setiap artikel jurnal disajikan oleh satu orang atau lebih yang bertindak sebagai penulis. Penulis artikel adalah orang yang menulis atau membuat artikel sedangkan kepenulisan adalah perihal penulis atau segala sesuatu yang berkaitan dengan penulis. Karakteristik kepenulisan artikel adalah ciri-ciri khusus yang melekat pada penulis artikel (Depdiknas, 2008). Pada umumnya, muatan informasi jurnal berupa hasil-hasil penelitian dalam bidang ilmu tertentu dan disajikan oleh satu orang penulis atau lebih. Dengan demikian, penulis artikel dalam jurnal juga bertindak sebagai peneliti.

Kartakteristik penulis dalam kajian ini, meliputi jenis kelamin, jenis pekerjaan, instansi asal, dan pendidikan penulis. Jenis kelamin dikelompokkan menjadi dua, yaitu pria dan wanita; jenis pekerjaan dibatasi pada tiga jenis pekerjaan: (a) dosen atau staf pengajar yaitu penulis yang mempunyai tugas pokok harian sebagai pengajar di institusi perguruan tinggi; (b) peneliti yaitu penulis yang memiliki tugas pokok sebagai peneliti atau melakukan penelitian; dan (c) mahasiswa dalam hal ini mahasiswa yang hendak mempublikasikan tugas akhirnya baik skripsi, tesis, maupun disertasi. Selanjutnya, karakteristik kepenulisan yang berkaitan dengan asal instansi, dalam kajian ini dibedakan menjadi tiga kelompok instansi: (a) Fakultas Psikologi UGM; (b) Fakultas di luar psikologi dalam lingkungan UGM; dan (c) instansi di luar UGM. Karakteristik kepenulisan berdasarkan latar belakang pendidikan dibedakan menjadi tiga kelompok, yaitu sarjana, magister, dan doktoral.

Karakteristik artikel merupakan ciri-ciri yang dapat dikenali dalam sebuah artikel. Dalam kajian ini, karakteristik artikel meliputi bahasa pengantar artikel, panjang artikel, subjek artikel, dan metodologi atau metode penelitian yang digunakan artikel. Karakteristik artikel berdasarkan bahasa pengantar dikelompokkan menjadi dua yaitu: (a) artikel yang berbahasa Indonesia; dan (b) artikel yang berbahasa asing. Karakteristik artikel berdasarkan 
subjek, dibagi dalam enam kelompok, yaitu: (a) psikologi industri dan organisasi; (b) psikologi perkembangan; (c) psikologi pendidikan dan psikometri; (d) psikologi sosial; (e) psikologi umum dan eksperimen; dan (f) psikologi klinis dan konseling. Pengelompokan ini dilakukan berdasarkan kurikulum program sarjana tahun 1990 sesuai dengan SK Dirjen Dikti Depdikbud RI No. 22/DIKTI/Kep/1985 (Fakultas Psikologi, 1990).

Pendekatan metode penelitian secara umum dibedakan menjadi dua, yaitu kuantitatif dan kualitatif. Menurut Creswell dalam Alsa (2003), penelitian kuantitatif adalah penelitian dengan data berupa bilangan (skor, nilai, peringkat atau frekuensi). Data tersebut dianalisis dengan menggunakan metode statistik guna menjawab pertanyaan penelitian. Ada dua rancangan utama dalam penelitian kuantitatif, yaitu: (a) penelitian dengan menggunakan intervensi, apakah suatu intervensi berpengaruh terhadap perilaku suatu kelompok yang berbeda dengan kelompok lain yang tidak mendapat intervensi (penelitian ini disebut juga penelitian eksperimen); (b) penelitian tanpa intervensi, antara lain penelitian korelasional, penelitian deskriptif, penelitian evaluasi, dan lain-lain (penelitian ini disebut juga penelitian non-eksperimen atau survei). Apabila data yang dikumpulkan dalam sebuah penelitian berupa kata-kata atau gambar, penelitian tersebut termasuk dalam kategori penelitian dengan metode kualitatif. Data penelitian kualitatif meliputi transkrip interview, catatan lapangan, fotografi, video tapes, dokumen personal, memo, dan catatan resmi lain.

Metode penelitian kuantitatif dan kualitatif dapat digabungkan dalam suatu kegiatan penelitian yang dinamakan metode penelitian kombinasi atau campuran. Metode penelitian kombinasi merupakan metode penelitian yang mengkombinasikan atau menggabungkan antara metode kuantitatif dan metode kualitatif untuk digunakan secara bersama-sama dalam suatu kegiatan penelitian sehingga diperoleh data yang lebih komprehensif, valid, reliabel dan objektif (Sugiyono, 2015). Karakteristik artikel berdasarkan metodologinya dalam kajian ini dikelompokkan menjadi empat metode, yaitu kualitatif, survei, eksperimen, dan campuran.

\subsection{Jurnal Psikologi UGM}

Publikasi ilmiah yang terbit secara berkala atau biasa disebut jurnal merupakan salah satu syarat untuk penilaian akreditasi sebuah perguruan tinggi. Oleh karena itu, sudah selayaknya setiap perguruan tinggi menerbitkan lebih dari satu jurnal sesuai dengan program studi yang diselenggarakan. Ada dua publikasi berkala yang diterbitkan Fakultas Psikologi UGM dan salah satunya berjudul Jurnal Psikologi UGM. Jurnal tersebut diterbitkan sejak tahun 1970-an. Keterbatasan pengelolaan menyebabkan terbitan perdana jurnal tersebut tidak tersimpan dalam arsip. Meskipun demikian, Perpustakaan Fakultas Psikologi UGM masih menyimpan dua nomor penerbitan tahun 70-an, yaitu Jurnal Psikologi UGM tahun 1976 dan tahun 1979 masing-masing satu nomor penerbitan. Kedua jurnal tersebut secara fisik berukuran $24 \mathrm{~cm} \times 16 \mathrm{~cm}$, dengan sampul yang masih sederhana terbuat dari kertas buffalo berwarna biru. Pada saat itu, penerbitannya belum mencantumkan International Standard Serial Number (ISSN) dan belum dilengkapi dengan petunjuk atau panduan bagi penulis yang akan berpartisipasi menyajikan karya tulisnya dalam jurnal tersebut. Namun demikian, setiap penerbitannya sudah mencantumkan editorial board yang isinya meliputi nama dan alamat penerbit beserta susunan pengurus (pimpinan umum, dewan redaksi, dan sekretaris redaksi). 
Terbitan tahun delapan puluhan yang berhasil dikelola perpustakaan ada tiga nomor, yaitu tahun 1985, 1987, dan 1989 masing-masing satu nomor penerbitan. Tampilan fisiknya sudah berbeda dengan terbitan tahun 1970-an karena sampulnya sudah bukan kertas buffalo melainkan kertas yang lebih berkualitas, dan setiap penerbitan warna sampulnya berbedabeda. Terbitan tahun 1980-an sudah dilengkapi dengan nomor ISSN, mencantumkan tim redaksi dan lain-lain, petunjuk bagi penulis beserta format penulisan naskah. Perkembangannya terus meningkat dengan penyempurnaan di sana-sini dan tetap eksis sampai saat ini. Tampilan Jurnal Psikologi UGM saat ini sudah disesuaikan dengan standar yang berlaku, sudah terakreditasi nasional (2011-2016). Pada tahun 2015, untuk pertama kalinya, publikasi ini diterbitkan tiga kali dalam setahun, sebelumnya hanya dua kali setahun. Di samping itu, jurnal tersebut dapat diakses melalui web psikologi.ugm.ac.id.

\section{METODE}

Kajian ini merupakan kajian kuantitatif deskriptif. Kajian kuantitatif, yaitu kajian dengan pendekatan analisis menekankan pada data-data numerikal (angka) yang diolah dengan metode statistik. Kajian deskriptif merupakan bagian dari kajian kuantitatif dengan kedalaman analisis terbatas sampai pada taraf deskripsi. Kajian kuantitatif deskriptif menganalisis dan menyajikan data fakta secara sistematik sehingga dapat lebih mudah dipahami dan disimpulkan (Azwar, 1998). Pengumpulan data menggunakan metode dokumentasi, yaitu mengumpulkan data dari sumber-sumber tertulis dalam hal ini Jurnal Psikologi UGM. Subjek kajian berupa Jurnal Psikologi UGM yang tersedia di perpustakaan Fakultas Psikologi UGM (1970-an sampai 2015), dengan objek kajian berupa: (1) karakteristik kepenulisan meliputi jenis kelamin, jenis pekerjaan, instansi asal, pendidikan penulis; dan (2) karakteristik artikel meliputi bahasa pengantar artikel, panjang artikel, subjek artikel, dan metodologi artikel. Analisis data menggunakan tabel frekuensi dalam persentase. Perhitungan persentase dengan menggunakan rumus dari Kerlinger (1973). Penghitungan tingkat kolaborasi menggunakan formula Subramanyam (Prihanto, 2002). Seluruh proses analisis menggunakan bantuan program komputer MS Excel 2013.

\section{HASIL DAN PEMBAHASAN}

Jumlah jurnal yang berhasil dikumpulkan dalam kajian ini ada 53 nomor penerbitan yang menyajikan 327 artikel.

\subsection{Frekuensi Kepenulisan Artikel Ditinjau dari Jenis Kelamin, Instansi Asal, Jenis Pekerjaan, Tingkat Pendidikan, Jumlah Penulis, dan Tingkat Kolaborasi}

\subsubsection{Jenis Kelamin}

Secara keseluruhan, 327 artikel yang disajikan melibatkan 617 nama penulis. Penulis artikel dengan jenis kelamin wanita lebih tinggi persentasenya $(54,78 \%)$ daripada penulis pria $(45,21 \%)$. Sejumlah 617 nama tersebut berasal dari 316 nama yang berbeda, terdiri atas 190 wanita $(60,12 \%)$ dan 126 pria $(39,87 \%)$. Dengan demikian, keterlibatan wanita sebagai penulis artikel Jurnal Psikologi UGM lebih tinggi daripada pria, kondisi ini menunjukkan bahwa mayoritas wanita sivitas akademika dalam lingkup Fakultas Psikologi UGM cenderung memberi pengaruh 
dalam penulisan artikel jurnal tersebut. Kajian pendukung lainnya dilakukan oleh: (1) Tiew (2006) terhadap Library \& Information Science yang diterbitkan oleh Perpustakaan Negara Malaysia, ditemukan bahwa kontributor penulis wanita lebih tinggi $(65,74 \%)$ dari pada penulis pria $(34,26 \%)$; (2) Dorovolomo (t.th) terhadap Journal of Educational Studies 1978-2005 yang menunjukkan bahwa penulis artikel jurnal tersebut didominasi oleh wanita. Kondisi ini berbeda dengan kajian yang pernah dilakukan oleh Purnomowati $(2000 ; 2004)$ terhadap majalah ilmiah di Indonesia, yang menyatakan bahwa persentase penulis pria lebih tinggi dari pada penulis wanita. Hasil kajian Himawanto (2015) juga menunjukkan kondisi yang sama bahwa penulis pria lebih tinggi dari pada penulis wanita. Hasil-hasil kajian yang berbeda tersebut menunjukkan bahwa ada kecenderungan beberapa faktor yang berpengaruh terhadap tinggi rendahnya persentase penulis pria maupun wanita dalam jurnal atau majalah ilmiah. Faktor-faktor yang cenderung berpengaruh tersebut antara lain: bidang keilmuan, periode penerbitan jurnal, dan wilayah tempat penerbitan.

\subsubsection{Instansi Asal}

Apabila dilihat berdasarkan instansi asal, penulis yang berasal dari lingkup internal Fakultas Psikologi UGM mencapai urutan tertinggi sebesar 62,30\%, diikuti oleh penulis dari luar UGM (eksternal) sebesar 33,95\%, dan persentase terendah oleh penulis dalam lingkungan UGM sebesar 3,73\%. Hampir sama dengan hasil kajian Natakusumah (2014) terhadap Jurnal Teknologi Indonesia (JTI) yang diterbitkan oleh Lembaga Ilmu Pengetahuan Indonesia (LIPI), ditemukan bahwa keterlibatan penulis internal dalam hal ini staf di LIPI lebih tinggi daripada penulis eksternal. Tingginya penulis internal dalam artikel jurnal menunjukkan bahwa ada kecenderungan perasaan memiliki di kalangan internal dengan berpartisipasi menyumbangkan karya tulisnya agar terjaga keberlangungan penerbitan publikasi yang diterbitkan oleh lembaga induknya. Gambar 1 menunjukkan frekuensi kepenulisan artikel Jurnal Psikologi UGM berdasarkan instansi asal.

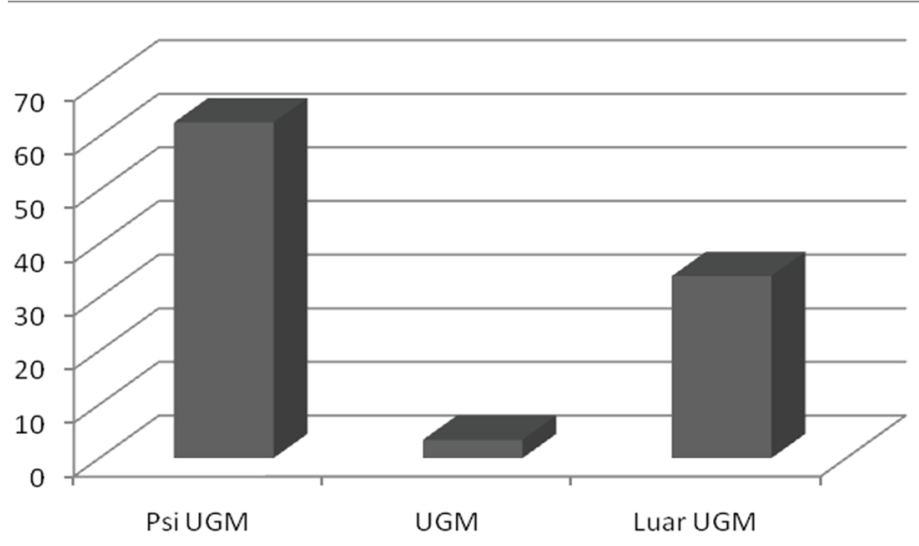

Gambar 1. Frekuensi kepenulisan artikel pada Jurnal Psikologi UGM berdasarkan instansi asal.

Pada Gambar 1 terlihat bahwa partisipasi penulis di luar Fakultas Psikologi UGM masih sangat rendah. Sementara itu, penulis eksternal dari luar UGM urutannya berada di atas, sekitar 50\% dari jumlah penulis internal dan sebagian besar dari mereka 
merupakan pakar psikologi di Indonesia. Kondisi ini menunjukkan bahwa pakar psikologi di Indonesia memberi kepercayaan dan menempatkan Jurnal Psikologi UGM sebagai media komunikasi ilmiah nasional bidang ilmu psikologi.

\subsubsection{Jenis Pekerjaan}

Berdasarkan 316 nama yang berbeda ditemukan bahwa jenis pekerjaan sebagai dosen menduduki peringkat tertinggi, sebesar 52,95\%. Peringkat di bawahnya sebesar $35,20 \%$ berstatus sebagai mahasiswa yang telah menyelesaikan tugas akhir, dan naskah publikasi tugas akhir tersebut memenuhi persyaratan dipublikasikan dalam Jurnal Psikologi UGM. Peringkat terendah sebesar 11,83\% disajikan oleh peneliti (lihat Gambar 2).

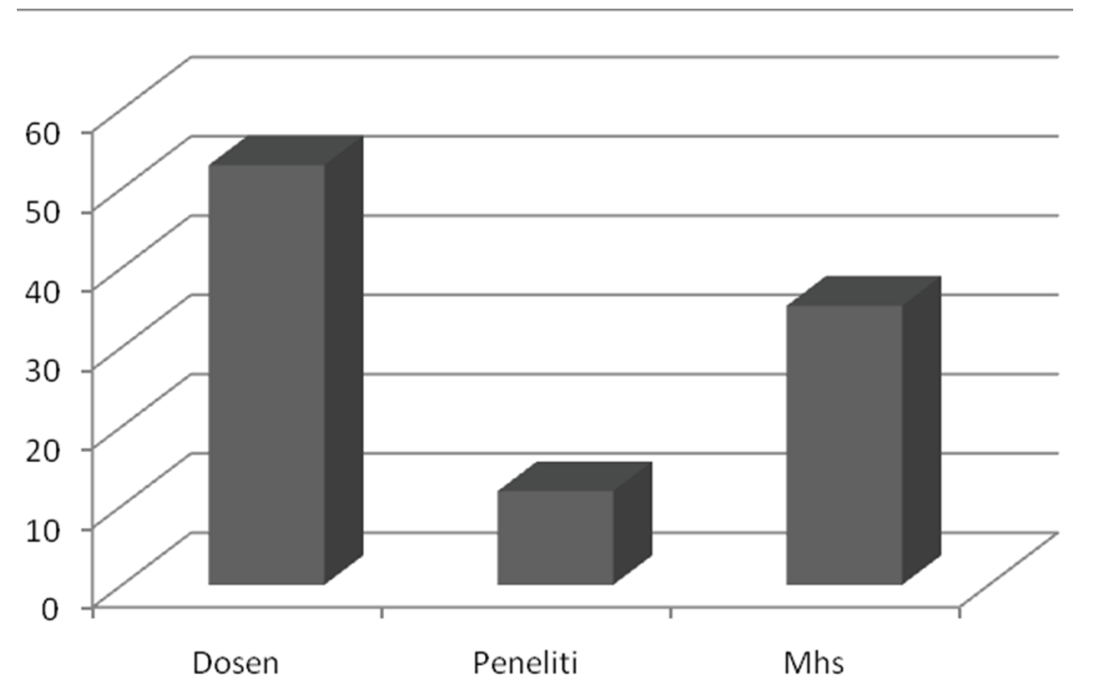

Gambar 2. Frekuensi kepenulisan artikel pada Jurnal Psikologi UGM berdasarkan jenis pekerjaan

Kondisi di atas menunjukkan bahwa perhatian dosen, khususnya dalam lingkup internal Fakultas Psikologi UGM, terhadap kebijakan pemerintah berkaitan dengan kenaikan pangkat dan jabatan cenderung lebih baik. Mereka telah berpartisipasi meningkatkan publikasi karya ilmiah di Indonesia meskipun secara kumulatif karya ilmiah di Indonesia yang berhasil dipublikasikan belum mencapai target yang ditentukan (Nasir, 2016). Hasil kajian ini berbeda dengan hasil kajian Natakusumah (2014) yang menunjukkan bahwa persentase penulis berstatus sebagai peneliti lebih tinggi daripada dosen. Perbedaan ini menunjukkan bahwa kecenderungan kuantitas populasi internal di mana jurnal tersebut diterbitkan berpengaruh terhadap partisipasi mereka dalam menyumbangkan artikelnya.

\subsubsection{Tingkat Pendidikan}

Tingkat pendidikan penulis dalam kajian ini dikelompokkan menjadi tiga kelompok yaitu sarjana (S1), magister (S2), dan doktoral (S3). Setelah dilakukan analisis terhadap 316 nama penulis yang berbeda, ditemukan bahwa penulis berpendidikan magister persentasenya tertinggi, yaitu $51,37 \%$, diikuti oleh penulis berpendidikan doktor sebesar $30,47 \%$, dan persentase terendah sebesar $18,15 \%$ merupakan penulis berpendidikan sarjana (lihat Gambar 3). 


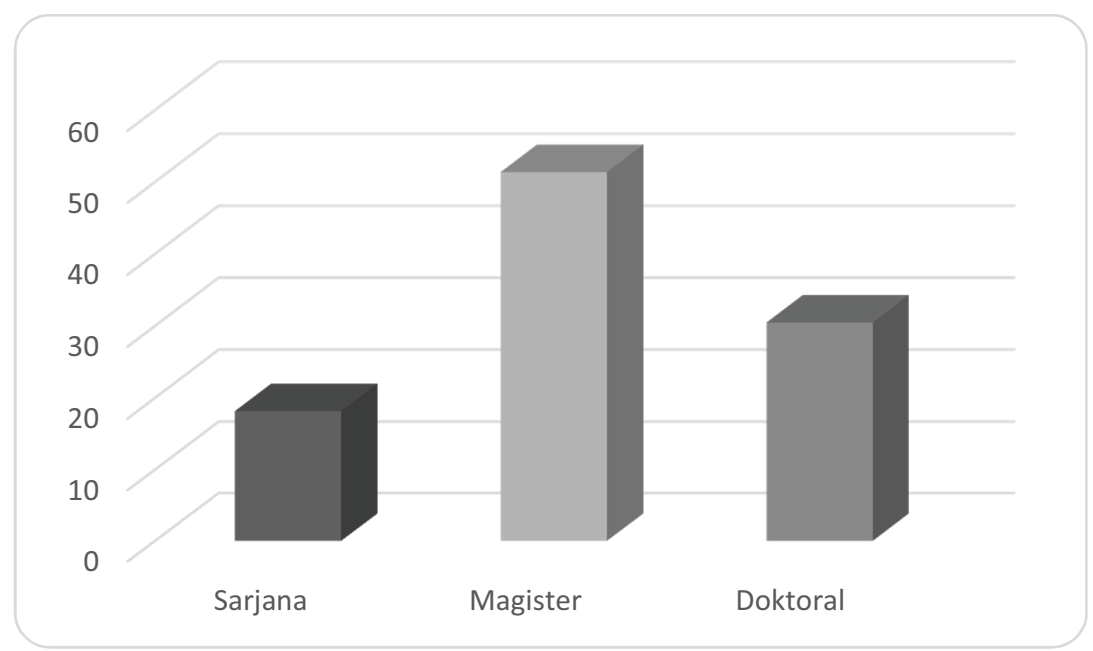

Gambar 3. Frekuensi penulis berdasarkan tingkat pendidikan

Gambar di atas menunjukkan bahwa sekitar $80 \%$ artikel yang dipublikasikan dalam Jurnal Psikologi UGM didominasi oleh penulis berpendidikan magister atau pascasarjana. Kepakaran yang lebih tinggi inilah yang merupakan salah satu bentuk dukungan terhadap Jurnal Psikologi UGM untuk menjadi jurnal berkualitas dan bereputasi dalam bidang keilmuan psikologi. Hasil kajian ini mendukung kajian Sutardji, dkk.(2004) yang menunjukkan bahwa jumlah penulis artikel yang dimuat dalam jurnal, buletin, dan prosiding terbitan Balitkabi, Puslitbangtan, dan Badan Litbang Pertanian berpendidikan S2 dan S3 lebih tinggi daripada penulis berpendidikan S1. Kondisi tersebut menunjukkan bahwa kecenderungan kemampuan dan kemauan menulis artikel dalam jurnal didominasi oleh penulis berpendidikan pascasarjana. Kemampuan metodologi yang lebih matang pada tingkat pendidikan ini, cenderung membuka peluang tulisan mereka diterima dan diterbitkan dalam jurnal bidang ilmu tertentu.

\subsubsection{Jumlah Penulis dan Tingkat Kolaborasi Penulis}

Seperti dikemukakan sebelumnya bahwa ada 327 judul artikel yang disajikan dalam 53 nomor penerbitan. Tiap artikel bervariasi penyajiannya bila ditinjau dari jumlah penulis yang terlibat. Hasil analisis data menunjukkan bahwa penyajian artikel secara bersama oleh beberapa penulis frekuensinya lebih tinggi $(56,88 \%)$ dari pada penulis tunggal (43,11\%). Meskipun berbeda bidang keilmuannya, hal ini mendukung kajian Natakusumah (2014) terhadap Jurnal Teknologi Indonesia, yang menemukan bahwa kepenulisan tunggal lebih rendah dari pada kepenulisan bersama. Demikian halnya dengan hasil kajian Paulsen dan Westemayer (2014) terhadap School Psychology International 2008-2013 yang menemukan bahwa kepenulisan tunggal lebih rendah dari pada kepenulisan bersama. Kondisi ini terjadi karena jurnal SPI merupakan jurnal bertaraf internasional sehingga dibutuhkan kerja sama antar-penulis sekaligus peneliti lintas negara untuk menghasilkan produk ilmiah yang bersifat internasional dan mempermudah publikasinya lewat SPI. Ketiga kondisi di atas menunjukkan bahwa karakteristik kepenulisan bersama atau kolaborasi penulis tidak dipengaruhi oleh perbedaan bidang keilmuan. Apabila dibuat grafik berdasarkan jumlah penulis akan terlihat seperti pada Gambar 4, yang menunjukkan bahwa 
penyajian artikel oleh penulis tunggal frekuensinya tertinggi $(43,11 \%)$, diikuti oleh penyajian artikel oleh dua penulis $(37 \%)$. Sementara penyajian artikel oleh tiga penulis frekuensinya pada urutan dibawahnya (14,06\%), diikuti penyajian artikel oleh empat penulis $(3,97 \%)$, dan penyajian artikel oleh penulis lima orang atau lebih, masingmasing menempati urutan yang sama $(0,91 \%)$. Meskipun penulis tunggal mencapai frekuensi tertinggi, tetapi nilainya masih berada di bawah 50\%. Tingginya frekuensi kepenulisan tunggal dapat terjadi karena beberapa aspek antara lain senioritas, pengalaman kerja, dan tingkat pendidikan sehingga penulis merasa belum memerlukan bantuan yang lain (Himawanto, 2015).

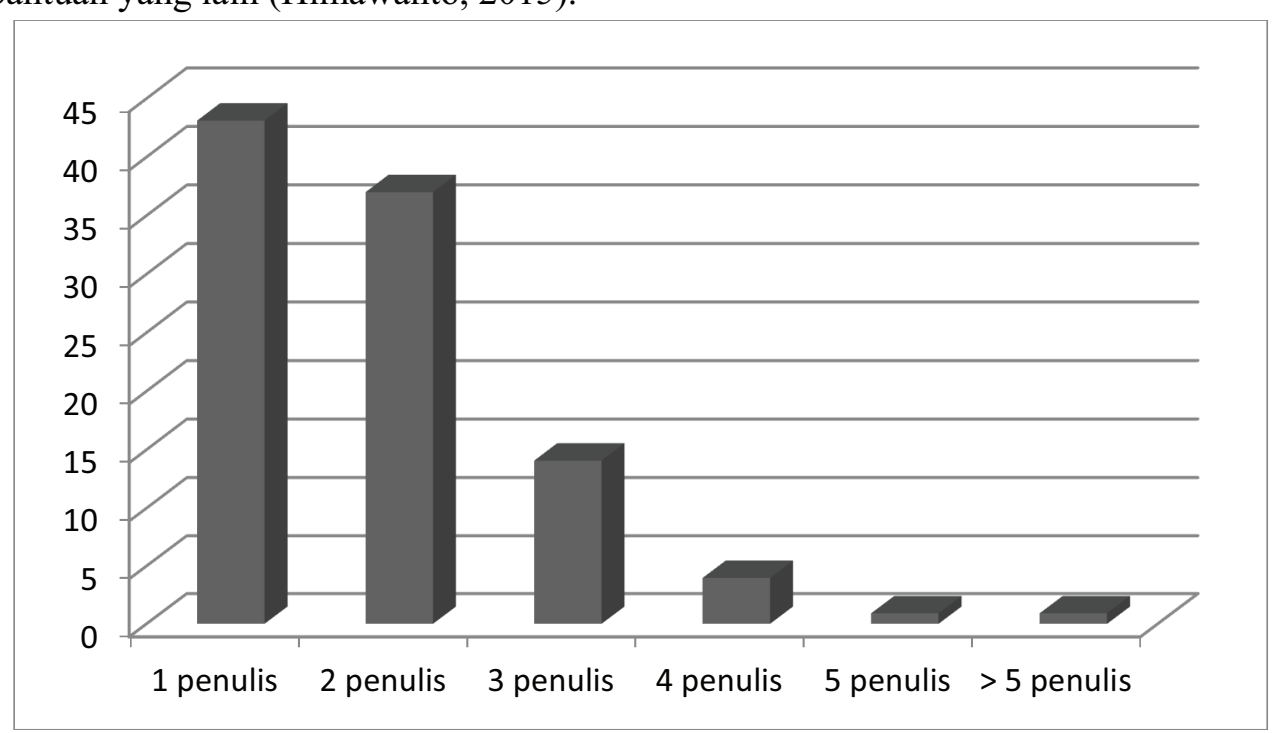

Gambar 4. Frekuensi artikel berdasarkan jumlah penulis

Perhitungan tingkat kolaborasi menggunakan formula Subramanyam (1983), ditemukan sebesar 0,56 yang berarti tingkat kolaborasi cenderung tinggi. Kondisi ini mendukung kajian yang pernah dilakukan oleh Zufrunnisha dan Pullareddy (2009) yang menemukan bahwa tingkat kolaborasi bidang ilmu psikologi sebesar 0,53. Berbeda dengan kajian yang dilakukan oleh Natakusumah (2014) bahwa penulis perorangan lebih rendah daripada penulis gabungan. Meskipun demikian, tingkat kolaborasi kedua kajian tersebut menunjukkan bahwa keduanya memiliki tingkat koleaborasi yang tinggi. Hal ini menunjukkan bahwa ada kecenderungan meningkatnya kolaborasi penulis dalam berbagai bidang keilmuan (Purnomowati, 2000).

\subsubsection{Keterlibatan Penulis}

Ada 316 nama berbeda yang terlibat dalam penulisan artikel Jurnal Psikologi UGM, frekuensi keterlibatan tertinggi sebanyak 16 kali, dan terendah sebanyak satu kali (Gambar 5). Gambar tersebut menunjukkan bahwa keterlibatan tertinggi diraih oleh Faturochman sebanyak 16 kali, Amitya Kumara dan JE Prawitasari masingmasing sebanyak 14 kali, Saifuddin Azwar sebanyak 13 kali, dan seterusnya. Kondisi ini memperkuat kajian yang pernah dilakukan Irianti (2015) bahwa Faturochman dan Saifuddin Azwar menduduki lima besar penulis yang terlibat sebagai penulis pertama pada Buletin Psikologi UGM 1993-2014. Pada gambar 5 juga dapat dilihat bahwa ada tiga nama penulis yang masing-masing terlibat dalam 12 artikel, yaitu Avin Fadilla 
Helmi, Subandi, dan Sugiyanto. Kemudian dua nama yang lain masing-masing terlibat dalam 10 artikel, yaitu Asmadi Alsa dan Budi Andayani. Lima besar penulis yang terlibat dalam penulisan artikel Jurnal Psikologi UGM semuanya berstatus sebagai Dosen Fakultas Psikologi UGM, demikian halnya dengan empat peringkat dibawahnya. Pada peringkat sepuluh dan seterusnya, diisi oleh penulis dari luar UGM, seperti Zulkaranain dari Fakultas Psikologi USU yang terlibat dalam lima artikel dan Soetarlinah Sukadji dari UPI-YAI yang terlibat dalam tiga artikel.

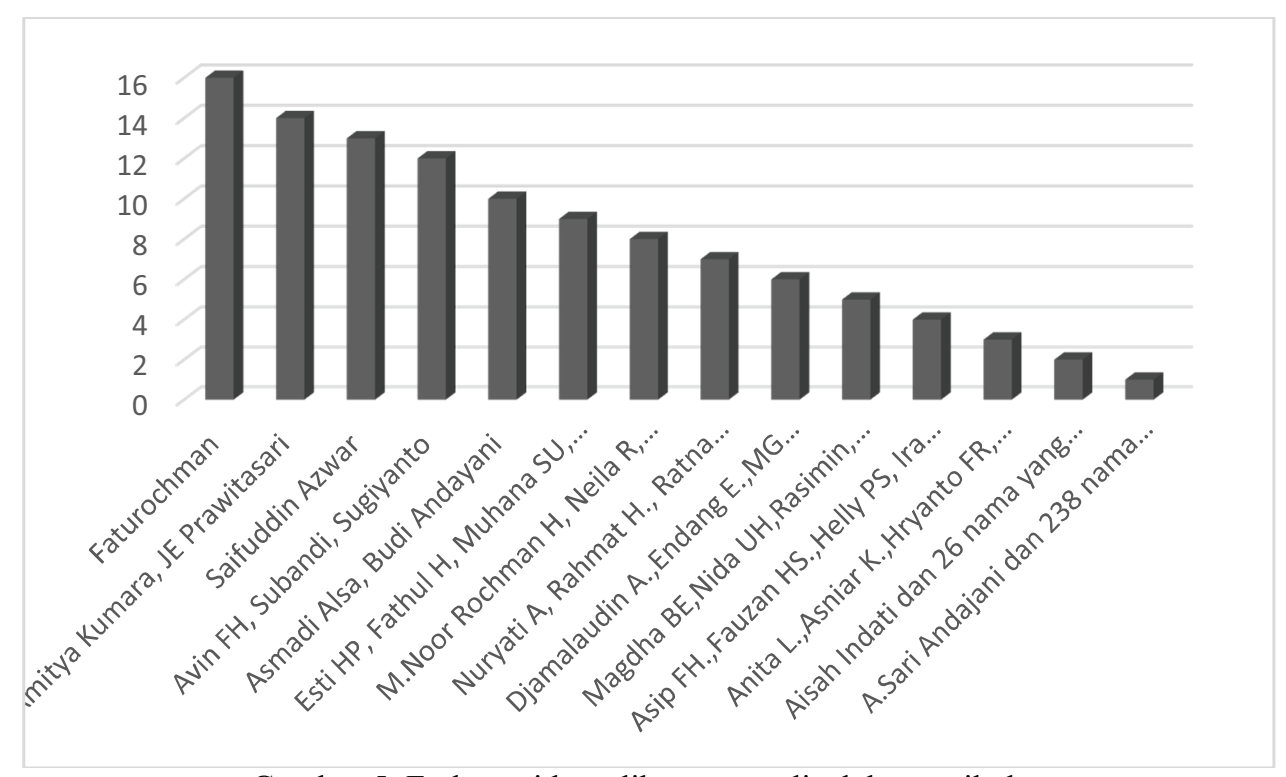

Gambar 5. Frekuensi keterlibatan penulis dalam artikel

\subsection{Karakteristik Artikel Berdasarkan Bahasa Pengantar Artikel, Panjang Artikel, Subjek Artikel, dan Metodologi yang Digunakan}

\subsubsection{Bahasa Pengantar}

Berdasarkan hasil perhitungan ditemukan bahwa dalam 327 artikel tersebut hampir seluruhnya berbahasa pengantar bahasa Indonesia $(92,96 \%)$ sedangkan yang lain berbahasa asing, dalam hal ini bahasa Inggris (7,04\%). Hasil kajian ini mendukung kajian Natakusumah (2014) terhadap Jurnal Teknologi Indonesia (JTI) bahwa artikel berhasa Indonesia lebih mendominasi dari pada artikel berbahasa asing atau bahasa Inggris. Demikian halnya dengan kajian Arik (2013) terhadap Turkish Journal of Psychology dan menemukan bahwa bahasa pengantar jurnal tersebut didominasi Bahasa Turki dari pada Bahasa Inggris. Hal ini menunjukkan bahwa kecenderungan menggunakan bahasa nasional berdasarkan wilayah geografi tempat jurnal tersebut diterbitkan lebih dominan dari pada penggunaan bahasa internasional atau bahasa Inggris. Hal tersebut dapat dilihat pada Gambar 6. 


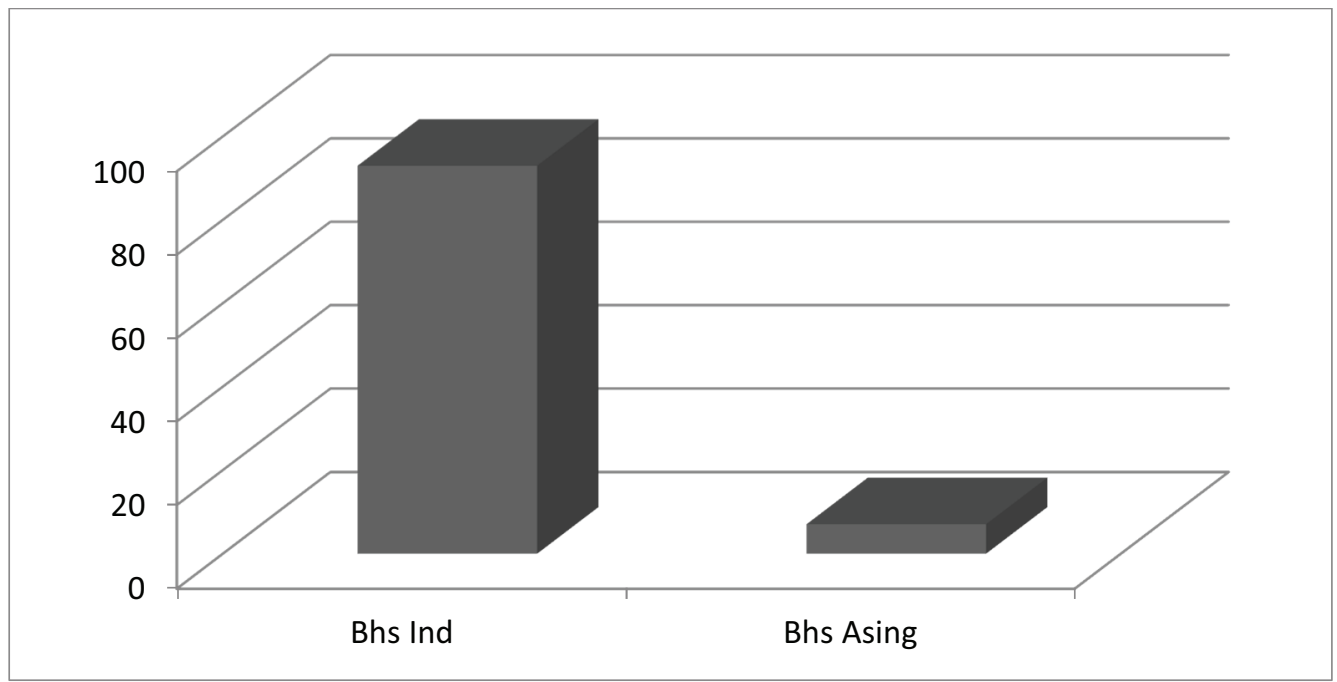

Gambar 6. Frekuensi artikel berdasarkan bahasa pengantar.

\subsubsection{Panjang Artikel}

Penghitungan panjang artikel dalam kajian ini dikelompokkan menjadi lima kelompok, yaitu (1-5); (6-10); (11-15); (16-20); dan (> 20) masing-masing dalam satuan halaman. Berdasarkan hasil analisis diperoleh hasil bahwa panjang artikel kelompok (11-15) menduduki frekuensi tertinggi, yaitu 41,9\%. Kelompok artikel dengan panjang halaman antara (6-10) menempati urutan kedua (30,9\%); kelompok (16-20) menempati urutan ketiga (19\%); dan urutan terendah (4,28\%), yaitu kelompok $(>20)$. Hal ini menunjukkan bahwa sekitar $90 \%$ artikel yang dipublikasikan panjangnya antara 6-20 halaman. Dengan demikian, hampir seluruh penulis artikel taat terhadap ketentuan yang diberlakukan meskipun batas maksimal panjang artikel dibatasi maksimal 25 halaman. Hasil perhitungan selengkapnya dapat dilihat pada Gambar 7.

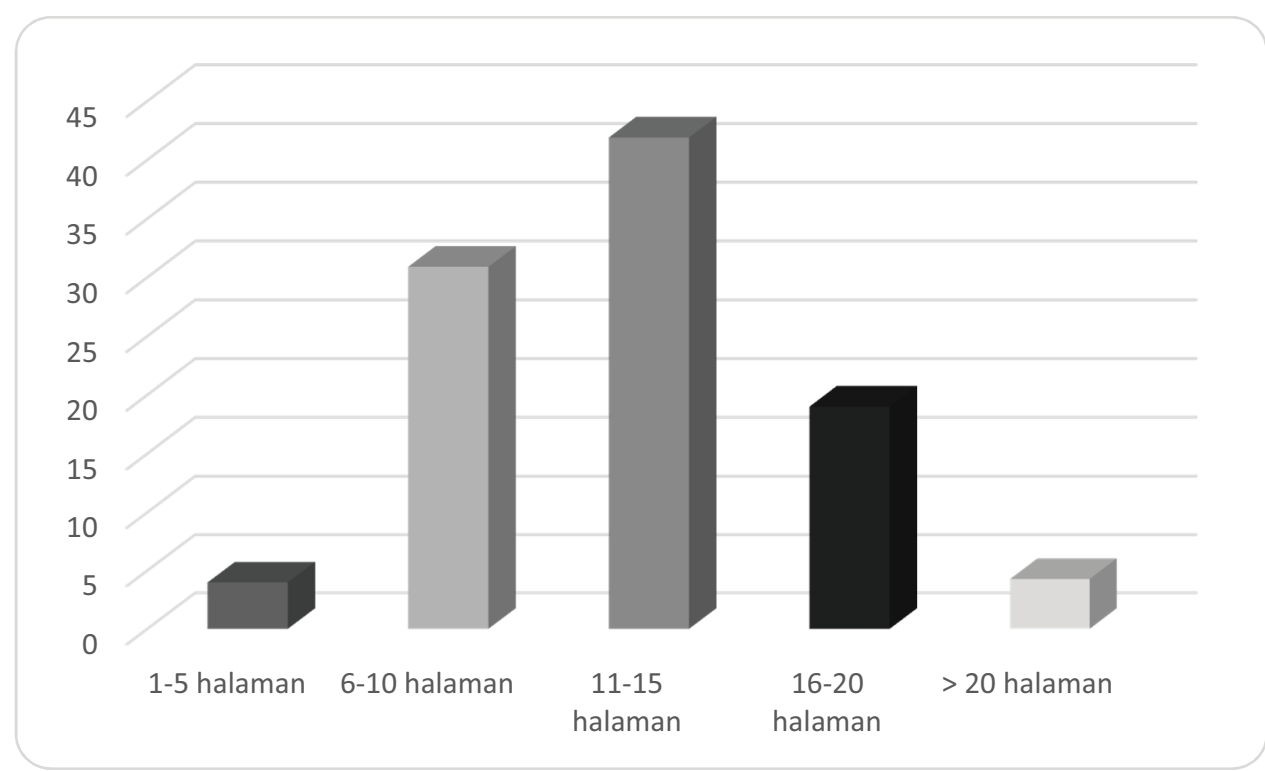

Gambar 7. Frekuensi panjang artikel berdasarkan lima kelompok jumlah halaman 
Temuan di atas mendukung kajian Das (2013) pada jurnal Library Trends bahwa panjang artikel dalam jurnal tersebut berkisar antara 16-20 halaman. Kondisi ini menunjukkan bahwa ada kecenderungan penulis taat pada ketentuan yang dibuat oleh setiap penebitan jurnal.

\subsubsection{Subjek Artikel}

Seperti dikemukakan dalam bab sebelumnya bahwa penentuan subjek artikel dikelompokkan dalam enam kelompok, yaitu (1) psikologi industri dan organisasi; (2) psikologi klinis dan konseling; (3) psikologi pendidikan dan psikometri; (4) psikologi perkembangan; (5) psikologi sosial; dan (6) psikologi umum dan eksperimen. Hasilnya ditemukan bahwa frekuensi subjek psikologi klinis dan konseling $(25,4 \%)$; psikologi sosial $(25,1 \%)$; psikologi pendidikan dan psikometri $(24,5 \%)$; psikologi industri dan organisasi $(13,8 \%)$; psikologi perkembangan $(8,56 \%)$; dan psikologi umum dan eksperimen (2,75\%). Psikologi klinis merupakan sebuah profesi yang membantu orang dan berkembang dengan cepat pada abad 20 di Amerika dan Eropa hingga menyebar ke seluruh dunia termasuk Indonesia. Posisi Psikologi klinis terus mengalami konsolidasi sebagai kekuatan yang signifikan dan produktif dalam kesehatan mental dan pelayanan kemanusiaan (Sundberg, 2007). Diasumsikan hal tersebut meningkatkan jumlah kajian bidang psikologi klinis termasuk di Fakultas Psikologi UGM dan sebagian besar dipublikasikan melalui Jurnal Psikologi UGM sehingga subjek psikologi klinis dan konseling frekuensinya ada di peringkat tertinggi. Hal tersebut dapat dilihat pada Gambar 8.

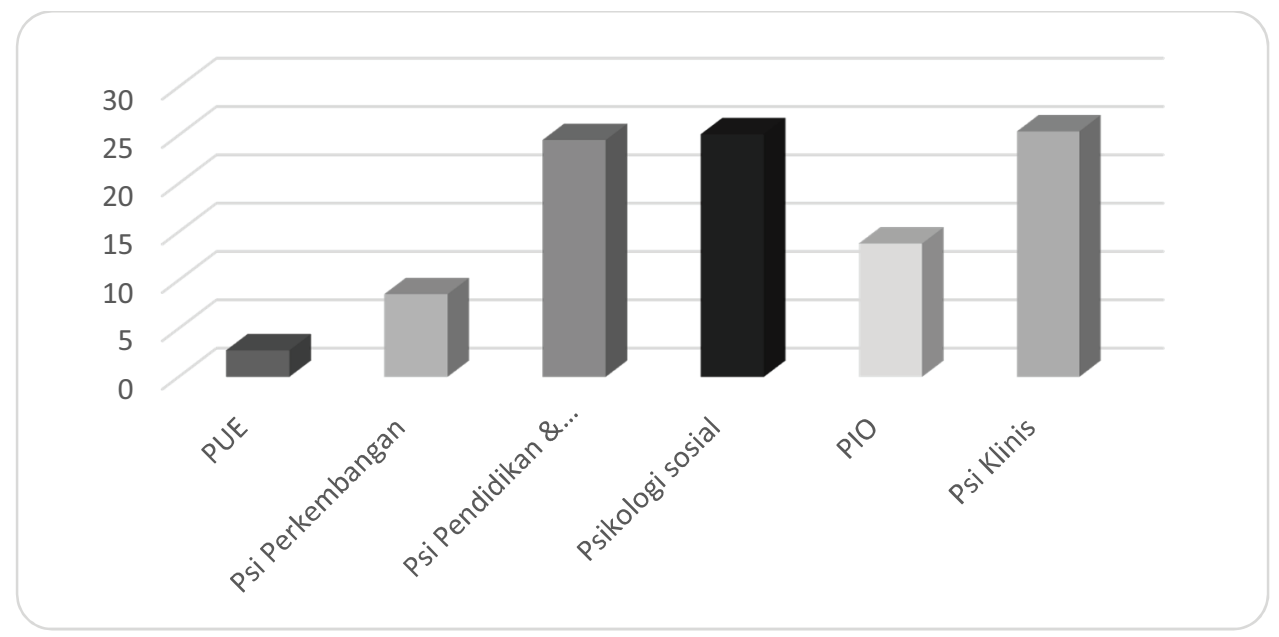

Gambar 8. Frekuensi artikel berdasarkan subjek

Kondisi ini mengindikasikan bahwa tingginya jumlah tulisan dengan subjek tertentu memberi peluang Fakultas Psikologi UGM menambah penerbitan jurnal psikologi dengan spesifikasi khusus.

\subsubsection{Pendekatan Metodologi Artikel}

Pengelompokan artikel berdasarkan metodenya dikelompokkan menjadi empat, yaitu: (a) kualitatif; (b) survey; (c) eksperimen; dan (d) campuran. Hasilnya menunjukkan bahwa persentase tertinggi artikel menggunakan metode survei (67,27\%); metode eksperimen (14,98\%); metode kualitatif (12,84\%); dan metode 
campuran (4,89\%). Hal tersebut dapat dilihat pada Gambar 9. Kondisi ini menunjukkan bahwa metode survei yang termasuk dalam metode kuantitatif noneksperimen merupakan metode yang lebih banyak digunakan dari pada metode lain. Pengumpulan data dalam kajian survei menggunakan angket atau skala, dianalisis dengan mendeskripsikan sikap, opini, perilaku, atau karakteristik responden, selanjutnya peneliti membuat pernyataan kecenderungan yang ada dalam populasi berdasarkan hasil survei (Alsa, 2003). Diasumsikan pendekatan ini lebih hemat waktu, tenaga, dan biaya sehingga para peniliti lebih banyak yang menggunakan metode survei sebagai pendekatannya. Berbeda dengan metode campuran yang membutuhkan data kuantitatif (kuesioner atau angket) maupun data kualitatif (wawancara dan observasi) serta data studi dokumentasi (Sugiyono, 2015). Semua data tersebut membutuhkan waktu yang tidak sedikit untuk pengambilan dan pengolahannya, demikian halnya dengan dana yang dibutuhkan. Hal ini mengakibatkan kajian dengan pendekatan ini lebih banyak dihindari, akibatnya jumlah kajiannya sangat sedikit.

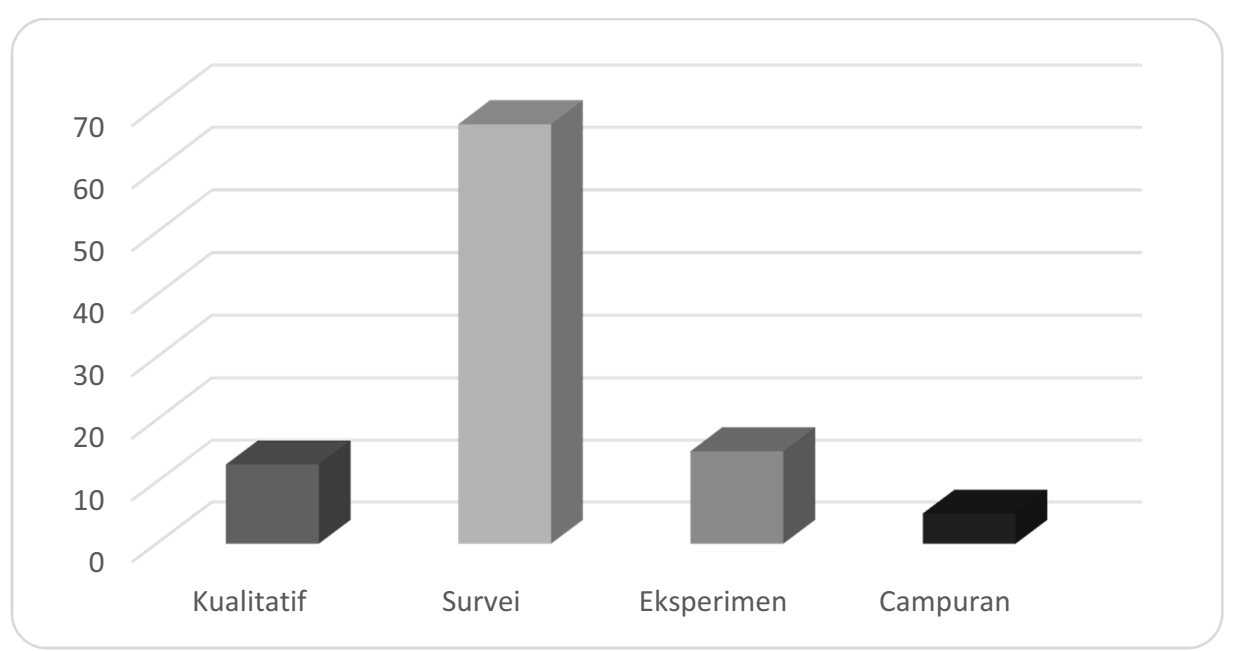

Gambar 9. Frekuensi artikel berdasarkan pendekatan metodologi yang digunakan

Tabel 1 menunjukkan frekuensi artikel berdasarkan pendekatan metodologi dalam empat kelompok tahun penerbitan Jurnal Psikologi UGM .

Tabel 1. Frekuensi Artikel Berdasarkan Pendekatan Metodologi Penelitian Jurnal Psikologi UGM

\begin{tabular}{|c|c|c|c|c|}
\hline \multirow{2}{*}{ Tahun } & \multicolumn{4}{|c|}{ Metode Penelitian } \\
\cline { 2 - 5 } & \multirow{2}{*}{ Kualitatif } & \multicolumn{2}{|c|}{ Kuantitatif } & \multirow{2}{*}{ Campuran } \\
\cline { 2 - 5 } & & Survei & Eksperimen & \\
\hline 1970 -an & - & $100 \%$ & - & - \\
\hline 1980 -an & - & $94,44 \%$ & $5,55 \%$ & - \\
\hline 1990 -an & $5,74 \%$ & $70,11 \%$ & $20,68 \%$ & $3,44 \%$ \\
\hline 2000 -an & $17,45 \%$ & $62,26 \%$ & $14,15 \%$ & $6,13 \%$ \\
\hline
\end{tabular}

Pada Tabel 1 terlihat bahwa penerbitan tahun 1970-an dan 1980-an penggunaan metode survei lebih mendominasi dari pada metode yang lain. Penerbitan tahun 1990 
sampai saat ini penggunaan keempat metode sudah dilakukan meskipun metode survei frekuensinya tetap paling tinggi.

\section{KESIMPULAN}

Berdasarkan hasil analisis menunjukkan bahwa karakteristik kepenulisan: (1) wanita lebih tinggi persentasenya $(60,12 \%)$ dari pada pria; (2) sebagian besar penulis bekerja sebagai dosen (52,95\%); (3) penulis internal dari Fakultas Psikologi UGM persentasenya paling tinggi $(62,30 \%)$; dan (4) penulis dengan tingkat pendidikan pascasarjana atau magister mencapai $80 \%$. Persentase kepenulisan bersama (56,88\%) lebih tinggi dari pada kepenulisan tunggal $(43,11 \%)$, dengan tingkat kolaborasi sebesar $0,56 \%$. Frekuensi keterlibatan penulis dalam artikel, persentase tertinggi diraih oleh Faturochman. Kemudian diikuti oleh Amitya Kumara, JE Prawitasari, dan Saifuddin Azwar. Karakteristik artikel berdasarkan bahasa pengantar ditemukan bahwa bahasa Indonesia frekuensinya lebih tinggi (92,96\%) dari pada bahasa asing. Panjang artikel antara 11-15 halaman frekuensinya juga lebih tinggi (41,9\%) dari yang lain. Ada tiga subjek yang menduduki posisi hampir sama (24\% - 25\%), yaitu psikologi klinis dan konseling; psikologi social; psikologi pendidikan dan psikometri. Pendekatan survei merupakan satusatunya pendekatan metodologi yang paling banyak digunakan dalam artikel $(67,27 \%)$. Penulis menyarankan perlu dibuat kebijakan baru oleh pengelola jurnal untuk meningkatkan penggunaan bahasa internasional sebagai bahasa pengantar artikel. Hal tersebut dilakukan agar dapat mengangkat Jurnal Psikologi UGM menjadi jurnal yang berkualitas dan bereputasi internasional.

\section{DAFTAR PUSTAKA}

Alsa, A. 2003. Pendekatan Kuantitatif dan Kualitatif serta Kombinasinya dalam Penelitian Psikologi. Yogyakarta: Pustaka Pelajar.

Arik, E. 2013. A Bibliometric Analysis of a National Journal: The Case of the Turkish Journal of Psychology. Journal Scientometrics Research, Vol.2, No.3, 173-184.

Arikunto, S. 2010. Prosedur Penelitian: Suatu Pendekatan Praktik. Jakarta: Rineka Cipta.

Azwar, S. 1998. Metode Penelitian. Yogyakarta: Pustaka Pelajar.

Das, T.K. 2013. A Bibliometric Analysis of Contributions in the journal 'Library Trends'. Library Philosophy and Practice. (http//digitalcommons.unl.edu/libphilprac, diakses 9 September 2016).

Depdiknas. 2008. Kamus Besar Bahasa Indonesia Pusat Bahasa. Jakarta: Gramedia Pustaka Utama.

Diodato, V. 1994. Dictionary of Bibliometrics. New York: The Haworth Press.

Dorovolomo, J. (t.th). "Characteristics of Authorship and Papers to an Educational Research in the Pacific Islands: Pacific Islands Educational Journal". (http://ijm.cgpublisher. com/product/ pub.28/prod.1225, diakses 9 September 2016).

Dwiputrianti, S. 2016. "Pentingnya Publikasi dan Akses Hasil Penelitian”. (http://stialanbandung. ac.id/index.php?option=com_content\&view $=$ article\&id=735:pentingnya-publikasi-danakses-hasil-penelitian-\&catid=12:artikel\&Itemid=85, diakses 29 Agustus 2016).

Fakultas Psikologi UGM. 1990. Buku Pedoman Fakultas Psikologi. Yogyakarta: Fakultas Psikologi UGM.

Glanzel, 2003. "Bibliometric as a Research Field". (http://www.cin.ufpe.br/ ajhol/futuro/ references/ 
01\%23_Bibliometrics_Module_KUL_BIBLIOMETRICS\%20AS\%20A\%20RESEARCH \%20FIELLD.pdf, diakses 5 September 2016).

Hartinah, S. 2012. "Kualitas Jurnal Ilmiah Tanah Air Rendah". (http://lipi.go.id/berita/kualitasjurnal-ilmiah-tanah-air-rendah/7665, diakses 29 Agustus 2016).

Himawanto. 2015. Kajian Bibliometrik terhadap Artikel Bidang Teknologi Minyak dan Gas Bumi di Indonesia (Biblometric Study of The Oil and Gas Technology Fiels in Indonesia). BACA: Jurnal Dokumentasi dan Informasi, Vol.36, No.1, 11-30.

Himawanto. 2015. Kajian Bibliometrika Riset Minyak dan Gas Bumi Nasional 1990-2014. Khizanah Al Hikmah : Jurnal Ilmu Perpustakaan, Informasi, dan Kearsipan. Vol.3, No.1, 49-53.

Irianti, Pergola. 2011. Pola Kepengarangan Jurnal Psikologi UGM Terbitan Tahun 2001-2010. Yogyakarta: Fakultas Psikologi UGM.

Irianti, Pergola. 2015. Keterlibatan Penulis dalam Artikel pada Buletin Psikologi Universitas Gadjah Mada. Berkala Ilmu Perpustakaan dan Informasi, Vol. XI, No.1, 17-24.

Kerlinger, FN. 2000. Foundations of Behavioral Research. California: Harcourt College Publisher.

Mishra, DK., Gawde, M., Solanki, MS. 2014. Bibliometric Study of Ph.D. Thesis in English. Journal of Academic Librarianship. Vol.1, No.1, 19-36.

Nasir, M. 2016. "Jumlah Penelitian dan Publikasi Penelitian Masih Rendah". (http://lipi.go.id/lipimedia/jumlah-peneliti-dan-publikasi-penelitian-masih-rendah-/15153, diakses 29 Agustus 2016).

Natakusumah, E.K. 2014. Penentuan Kolaborasi Penelitian dan Distribusi Pengarang pada Jurnal Teknolgi Indonesia (The Determinations of Research Collaborations and Authors Distribution in the Jurnal Teknologi Indonesia). BACA: Jurnal Dokumentasi dan Informasi, Vol.35, No.1, 15-23.

Panda, I., Maharana, B., Chhatar, DC. 2013. The Journal of Information Literacy: Bibliometric Study. International Journal of Scientific and Research Publications, Vol.3, Issue 3, 1-7.

Paulsen, K. and Westemayer, K. 2014. A Bibliometric Analysis of School Psychology International 2008-2013: What is the Prevalence of International Affairs in the Field of School Psychology?. Journal of Undergraduatre Research at Minnesota State University, Mankato. Vol.14, Article7.

Prihanto, I.G. 2002. Kolaborasi. Kumpulan Makalah Kursus Bibliometrika. Depok: Masyarakat Informetrika Indonesia.

Purnomowati, S. 2004. Ciri-Ciri Kepengarangan dan Penggunaan Literatur dalam Majalah Indonesia Bidang Ilmu-Ilmu Sosial. BACA: Jurnal Dokumentasi dan Informasi, Vol.28, No.1, 15-29.

Purnomowati, S. dan Yuliastuti, R. 2000. Pola Kepengarangan dalam Majalah BACA tahun 19741999”. BACA: Jurnal Dokumentasi dan Informasi, Vol.25, No.1-2, 20-30.

Regolini, A. and Jannes-Ober, E. 2013. A Bibliometric Study of Informing Science: The International Journal of an Emerging Transdiscipline. Informing Science: the International Journal of an Emerging Transdiscipline, Vol.16.

Roy, S.B and Basak, M. 2013. Journal of Documentation: a Bibliometric Study. Library Philosophy and Practice.

Sugiyono. 2015. Metode Penelitian Kuantitatif, Kualitatif dan Kombinasi (Mixed Methods). Bandung: Alfabeta. 
Sulistyo-Basuki. 2002. Bibliometrika, Sainsmetrika, dan Informetrika. Kumpulan Makalah Kursus Bibliometrika. Depok: Masyarakat Informetrika Indonesia.

Sundberg, N.D., Winerbarger, AA., Taplin, JR. 2007. Psikologi Klinis, Perkembangan Teori, Praktik, Dan Penelitian. Diterjemahan dari judul asli: Clinical Psychology oleh Helly PS dan Sri Mulyantini S. Yogyakarta: Pustaka Pelajar.

Sutardji dan Maulidyah, S.I. 2014. Analisis Bibliometrika pada Buletin Palawija. Jurnal Perpustakaan Pertanian, Vol.23, No.1, 17-23.

Sutardji, Sutarno, dan Maulidyah. 2004. Hubungan Antara Tingkat Pendidikan Peneliti dengan Dokumen yang Disitir pada Karya Tulis Ilmiah. BACA: Jurnal Dokumentasi dan Informasi, Vol.28, No.2, 95-105.

Thanuskodi, S. 2011. Bibliometric Analysis of the Indian Journal of Chemistry. Library Philosophy and Practice.

Tiew, W.S. 2006. Authorship Characteristics in Sekitar Perpustakaan 1994-2003: A Bibliometric Study. Malaysian Journal of Library \& Information Science, Vol.11, No.1, 65-75.

Zufrunnisha, N. and Pullareddy, V. 2009. Authorship Pattern and Degree of Collaboration in Psychology. Annals of Library and Information Studies, Vol.56, 255-261. 
